\title{
Surgical Treatment of Ebstein's Anomaly
}

\author{
Melchior Burri ${ }^{1}$ Rüdiger Lange ${ }^{1,2}$ \\ ${ }^{1}$ Clinic for Cardiovascular Surgery, German Heart Centre Munich at \\ the Technical University, Munich, Germany \\ 2 DZHK (German Centre for Cardiovascular Research), Partner Site \\ Munich Heart Alliance, Munich, Germany
}

\begin{abstract}
Address for correspondence Melchior Burri, MD, Department of Cardiovascular Surgery, Deutsches Herzzentrum Munchen des Freistaates Bayern, Lazarettstraße 36, 80636 Munich, Germany (e-mail: burri@dhm.mhn.de).
\end{abstract}

Thorac Cardiovasc Surg 2017;65:639-648.

\begin{abstract}
Keywords

- heart valve surgery

- congenital heart disease

- CHD

- tricuspid valve

Surgical repair of the tricuspid valve is a milestone in the medical history of patients with Ebstein's anomaly. The timely alleviation of the insufficiency has an important impact on the prognosis. In this review, we describe features of the disease relevant to surgical correction and the evolution of surgical techniques over six decades. We compare the results of different repair and replacement techniques. Additionally, we discuss concomitant antiarrhythmic surgery and bailout strategies for postoperative right ventricular failure. Finally, we review the surgical options in symptomatic neonates with Ebstein's disease.
\end{abstract}

\section{Introduction}

With an incidence of 5.2 per 100,000 live births, Ebstein's anomaly accounts for $1 \%$ of all congenital heart disease. ${ }^{1}$ Its main features are a pathologic configuration and attachment of the tricuspid leaflets that lead to severe insufficiency of the tricuspid valve and a pathologic configuration of the right ventricle. Additionally, an atrial septal defect (ASD) or a persistent foramen ovale (PFO) is present in two-thirds of patients, ${ }^{2}$ and cyanosis may develop due to interatrial right to left shunting. The onset of symptoms varies according to the severity of the disease. Some patients become symptomatic as neonates, others as young adults, and some remain free of symptoms until seniority. ${ }^{3}$

The anomaly is named after the pathologist, Wilhelm Ebstein, who first described it in $1866 .{ }^{4} \mathrm{~A}$ long time passed until the diagnosis could be made during lifetime in 1951, using cardiac catheterization. ${ }^{5}$ Since around 1980 , echocardiography simplifies detection and has become the standard method for diagnosis. The first surgical procedures in patients with Ebstein's disease were ASD closures in cyanotic patients, performed in 1956. The mortality of these procedures exceeded $80 \%{ }^{6}$ Since the results of isolated ASD closure were poor, physicians searched for ways to reduce the insufficiency of the aberrant valve. In 1956, the American surgeons, Lillehei and Hunter, planned to perform an ASD

received

March 30, 2017

accepted after revision

June 13, 2017

published online

August 14, 2017 closure combined with tricuspid valve repair in a 10-year-old girl with Ebstein's anomaly suffering from severe cyanosis. ${ }^{7}$ Due to the progressed heart disease, the patient died upon the induction of anesthesia. The two surgeons performed an autopsy and developed the first concept to repair the Ebstein valve anomaly. Later, this concept was successfully applied by Hardy, who performed the first successful repair of an Ebstein valve in $1963 .{ }^{8}$ One year earlier, the first valve replacement in a patient with Ebstein's disease was performed by Barnard in South Africa. ${ }^{9}$ Both repair and replacement of the tricuspid valve will be discussed in the section, "Surgical Techniques."

\section{Pathologic Anatomy and Pathophysiology}

\section{Leaflets}

The tricuspid valve develops by delamination of the leaflets from the underlying myocardium. ${ }^{10}$ In a healthy individual, the three leaflets (anterior, posterior, and septal) separate completely from the myocardium and their hinge point is located at the tricuspid annulus. In Ebstein's anomaly, the delamination process is incomplete and does not reach the tricuspid annulus. As a result, the leaflets are shortened and their hinge point lies inside the ventricle. The three leaflets are not uniformly affected. The septal and the posterior leaflets are displaced, and the highest degree of displacement
DOI https://doi.org/ 10.1055/s-0037-1604469. ISSN 0171-6425. (c) 2017 Georg Thieme Verlag KC Stuttgart · New York 


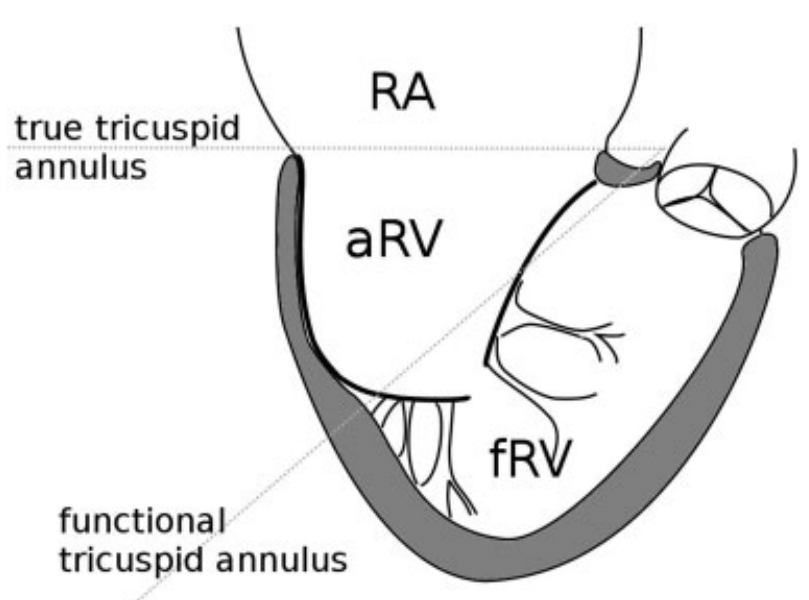

Fig. 1 Rotation of the functional tricuspid annulus toward the outflow tract. aRV, atrialized right ventricle; fRV, functional right ventricle; RA, right atrium.

is usually present at the internal crux of the heart, at the commissure between the two leaflets. The septal leaflet is small or even rudimentary. The anterior leaflet is usually not displaced and is enlarged rather than shortened. The displacement of the septal and posterior leaflets results in a rotation of the valve toward the outflow tract ${ }^{11}$ (-Fig. 1). Various degrees of connections with the myocardium are present at all leaflets, leading to their restriction. Often, there are holes in the leaflets that contribute to the insufficiency. The leaflets may have a free edge and chordae tendineae, but in some severe cases, the edge is directly connected to the myocardium and the papillary muscle.

\section{Ventricle and Myocardium}

At the atrioventricular groove, the true tricuspid annulus can still be identified. ${ }^{11}$ Due to the partial displacement of the valve toward the apex, the part of the right ventricle (RV) between the true and the anatomical tricuspid annulus becomes functionally a part of the atrium and is referred to as the "atrialized ventricle." The tricuspid annulus is severely enlarged, as well as the right atrium and the RV (-Fig.2). However, the functional RV is small compared with the gigantic right atrium and the atrialized ventricle. The volume of the entire RV, measured in magnetic resonance imaging, is two to three times larger compared with a normal RV. $^{12,13}$

The myocardium is altered at different sides. At the atrialized RV, the myocardium is usually thin or even absent. The wall thickness of the functional RV may be enlarged or thinned. ${ }^{14}$ At the left ventricular wall, an increase of interstitial fibrosis may be found. ${ }^{15,16}$ It is assumed that these alterations contribute to ventricular dysfunction and heart failure in Ebstein's disease.

\section{ASD}

In two-thirds of patients with Ebstein's anomaly, an ASD II/ PFO is present. If the right atrial pressure is elevated, as typically during exercise, a right to left shunt through the

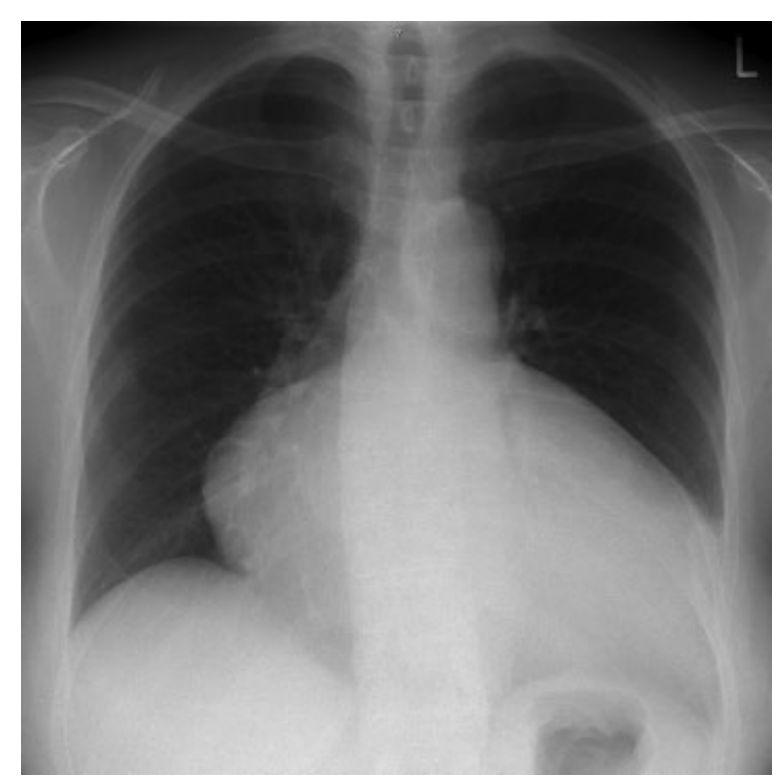

Fig. 2 Preoperative picture of a 61-year-old man with Ebstein's anomaly. The heart-thorax coefficient is 0.76 .

ASD II ensues. Oxygen saturation of the arterial blood is usually moderately impaired (80-90\% saturation). ${ }^{17}$ The right to left shunt on the atrial level may also account for paradoxical emboli. A quarter of patients beyond 40 years of age exhibit a history of an event potentially caused by paradoxical emboli, such as stroke, transient ischemic attack, brain abscess, or myocardial infarction. ${ }^{18}$

\section{Rhythm}

Patients with Ebstein's anomaly may present with different forms of arrhythmia. In one-third of the patients with tachycardia, one or more accessory pathways are present, usually at the posterolateral side of the RV. ${ }^{19}$ The enlarged atrium is susceptible for atrial flutter or fibrillation. - Table 1 provides an overview of the most common rhythm disorder in patients with Ebstein's anomaly. A potentially dangerous combination is the presence of an accessory pathway and the occurrence of a supraventricular tachycardia. The accessory pathway may conduct the supraventricular tachycardia in a 1:1 ratio to the ventricle. Accordingly, an atrial fibrillation may transform into ventricular fibrillation and result in sudden cardiac death. ${ }^{20}$ In patients with mild leaflet displacement, arrhythmia may be the most important symptom, and even sudden cardiac death has been reported in such patients. ${ }^{21}$

\section{Indication for Surgery}

The natural history of Ebstein's anomaly depends on the degree of tricuspid valve dysplasia. In 2000, Attie reported on 72 adult patients who had not received operative treatment. ${ }^{22}$ After 20 years of follow-up, survival was less than $10 \%$ in patients with a severe displacement of the septal leaflet $(n=14), 30 \%$ in patients with a mediocre displacement $(n=35)$, and $90 \%$ in patients with only minor displacement $(n=23)$, respectively. 
Table 1 Mechanism of tachycardia in patients with Ebstein's anomaly

\begin{tabular}{|l|l|}
\hline Primary & \\
\hline Accessory pathways & Bidirectional (WPW) \\
\hline & Mahaim fibers \\
\hline Other & AV nodal reentrant tachycardia \\
\hline Secondary & \\
\hline Atrial reentry tachycardia & Origin at atriotomy scar \\
\hline Atrial flutter & $\begin{array}{l}\text { Cavo-tricupsid isthmus } \\
\text { dependent }\end{array}$ \\
\hline & Atrial dilatation \\
\hline & Atrial fibrosis \\
\hline Atrial fibrillation & Atrial dilatation \\
\hline & Atrial fibrosis \\
\hline
\end{tabular}

Abbreviation: AV, atrioventricular; WPW, Wolff-Parkinson-White Syndrome.

In contrast, long-term survival 20 years after the surgery is reported to be 70 to $90 \% .{ }^{23-25}$ Thus, surgical treatment of the tricuspid valve regurgitation improves long-term outcome. Because both surgical risk and long-term mortality are increased for patients with advanced disease, surgery should not be delayed. ${ }^{24}$ Patients with severe regurgitation beyond 40 years of age should be carefully evaluated with regard to long-term sequelae of congestion, in particular renal, pulmonary, and hepatic failure. Severe left ventricular dysfunction is a risk factor for operative mortality, but it is not a contraindication for surgery. After surgery, left ventricular function usually improves. ${ }^{26}$

\section{Surgical Technique: Repair}

\section{Surgical Access}

The chest is opened through a median sternotomy. Pericardial traction sutures are placed, and after administration of heparin, the aorta and the caval veins are cannulated. The cannula in the superior caval vein should be placed more cranially, because in selected cases, a cavopulmonary connection might be needed to unload the RV permanently. The operation is performed under cardiopulmonary bypass with mild hypothermia on the cardioplegic arrested heart. Several traction sutures are placed at the right atrium to provide a perfect exposure of the valve (-Fig. $\mathbf{3}$ ).

\section{Plication Techniques}

The understanding of the plication techniques of the ventricular wall is a key point for the understanding of the different repair techniques. The size of the $\mathrm{RV}$ is reduced by folding the wall of the atrialized ventricle.

- The horizontal or transversal plication is intended to reduce the true tricuspid annulus.

- The longitudinal plication creates a fold from the tricuspid valve annulus toward the apex, thereby reducing the size of the annulus as well as of the atrialized ventricle. Ventricular plication bears the risk for coronary artery injury. Therefore, the coronary branches are continuously followed from the epicardium during plication.

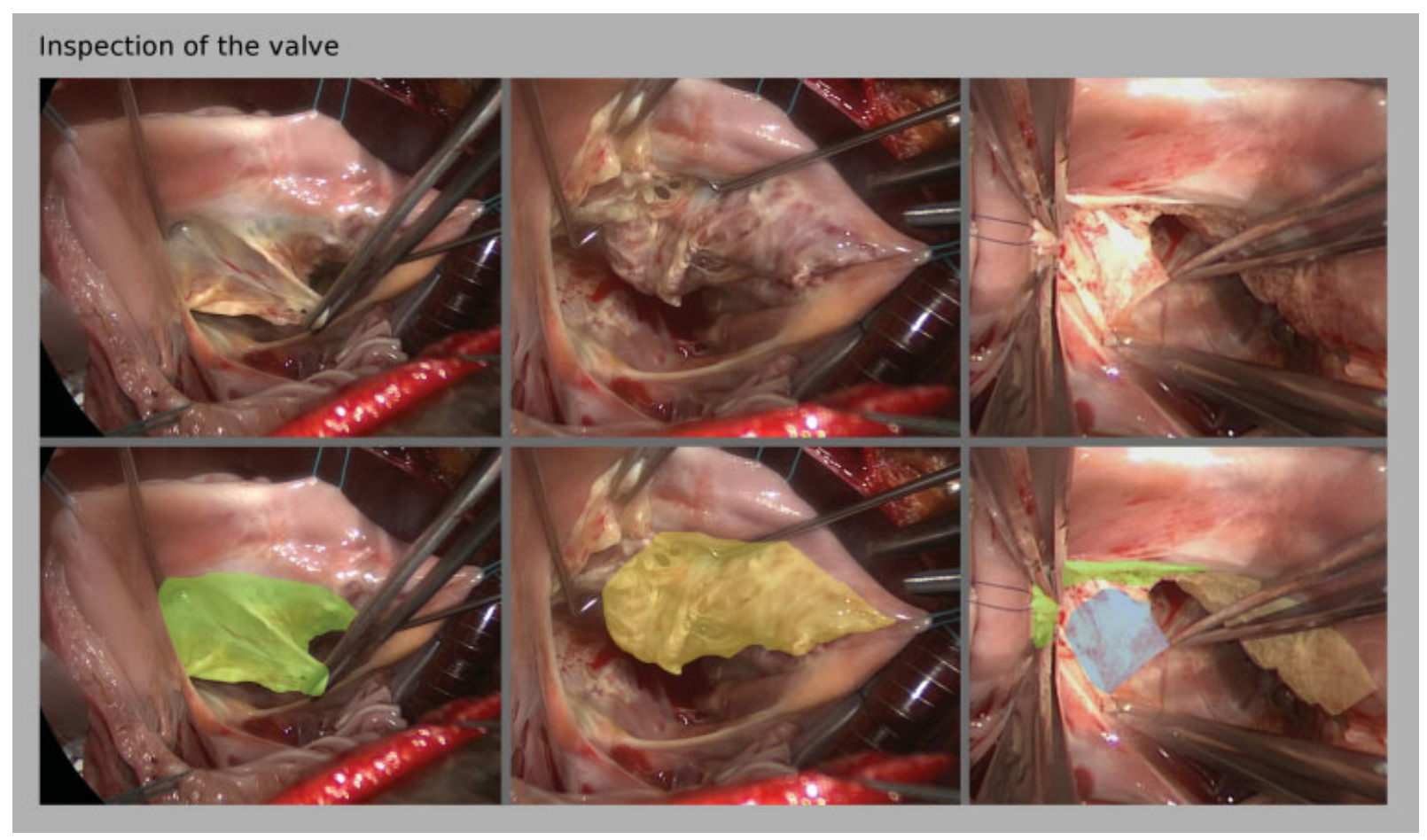

Fig. 3 Intraoperative inspection of the tricuspid valve. Green, anterior leaflet; yellow, posterior leaflet; blue, septal leaflet. The septal leaflet is severely displaced from the true annulus, the posterior leaflet is almost immobilized by adhesions toward the posterior wall. 


\section{Hunter-Lillehei-Hardy Technique}

The first concept to repair the Ebstein valve was developed by Hunter and Lillehei. ${ }^{7}$ Their goal was to "reestablish" the physiologic anatomy of the tricuspid valve by bringing the downward displaced septal and posterior leaflet to the "true" annulus without detaching the leaflets. This was achieved by plication of the RV in the horizontal (transverse) plane, i.e., in parallel to the tricuspid annulus. Stiches are placed from the base of the septal/posterior leaflet to the corresponding place at the true annulus. After tiding the sutures, the atrialized ventricle is excluded.

\section{Danielson Technique}

The Danielson technique ${ }^{27}$ is a modification of the Hardy technique. Danielson reasonably describes that the septal part of the atrialized ventricle is not suitable for plication, because a plication may affect mitral valve function, and the septum may bulge into the left ventricle. Consequently, the septal part is still not covered with leaflet tissue after plication. Therefore, an annular plication at the posterior part of the right ventricle is added. This brings the anterior leaflet toward the septum and may enhance the coaptation. This repair technique results functionally in a monocuspid valve since the posterior leaflet is almost excluded by the posterior ring plication and the septal leaflet remains as a remnant below the coaptation plane.

\section{Carpentier Technique}

The plication techniques for the repair of the Ebstein valve addressed the wrong target; the techniques addressed the ventricle instead of the leaflets. The leaflets of the Ebstein valve are "trapped" by multiple attachments, which prevent sufficient coaptation regardless of how much the ventricle is distorted by plication. As early as 1958, Lillehei and Hunter stated in their paper that the plication method was favored because of its relative ease of use but that a repositioning of the leaflets would be the more physiologic approach: "This plication maneuver would appear simpler, quicker, and more feasible than the previously considered procedure of cutting the leaflets free and reattaching them in a more normal position."7 Surgical techniques, suture material, cardiopulmonary bypass, and even cardioplegic arrest were not developed enough to allow for complicated reconstructions at that time.

Alain Carpentier with his ingenious and structured surgical imagination was the first to address the leaflets for reconstruction of the Ebstein valve. ${ }^{28}$ Carpentier described the disconnection of parts of the anterior and the posterior leaflet from the functional annulus at the hinge point, thereby gaining access to the multiple attachments behind the leaflets that prevent leaflet mobility. By dissection of these attachments, the whole leaflet tissue becomes available for repair. However, the chordae tendineae stay in place. Then, the RV and the true tricuspid annulus are reduced by performing a longitudinal plication of the posterior wall. The previously disconnected leaflets are rotated clockwise and reattached at the true tricuspid valve annulus. The anterior and posterior leaflets now act as a bicuspid valve at the height of the true tricuspid annulus. In adult patients, the annulus is enforced with a ring.

\section{Cone Technique}

The cone procedure developed out of the Carpentier repair. ${ }^{29}$ However, Da Silva's cone technique takes the severe downward displacement of the septal and part of the posterior leaflet more into consideration. With Carpentier's technique, where the valve is reconstructed in a "horizontal" plane, some of the displaced leaflet tissue is lost for repair. In contrast, the "cone valve" is not reconstructed in a "horizontal" plane but in the shape of a cone, predetermined by the Ebstein morphology.

Together with the posterior leaflet and the displaced part of the anterior leaflet, the septal leaflet is dissected free and mobilized extensively ( $\mathbf{- F i g}$. 4a-b). Parts of the septal leaflet are adherent to the ventricular wall and have to be "peeled off" the myocardium. For each leaflet, a chordae tendineae or a corresponding ventricular anchoring is retained. Similar to the Carpentier repair, a longitudinal plication is performed, reducing the size of the ventricle

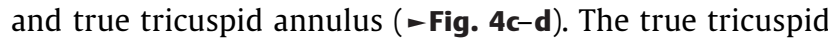
annulus is further reduced by annular plication to a size that all three leaflets cover the full circumference of the annulus (-Fig. $\mathbf{4 e - h}$ ). The leaflets are longitudinally attached to each other with a running suture such that the valve, which initially consisted of three separate leaflets is transformed into a valve with a single circular, cone-shaped leaflet, covering 360 degrees of the true tricuspid annulus. Even though the annulus is reduced extensively and the commissures are closed, there is usually no gradient over the newly created "cone-valve."

There are numerous modifications of the cone technique, including leaflet augmentation, ring annuloplasty, usage of autologous or artificial chordae, and the Sebening stitch. ${ }^{30}$ However, in our experience, the consequent application of the originally described cone technique alone is sufficient for successful valve construction in the majority of patients. ${ }^{13}$

\section{Wu Technique}

Mobilization of the leaflets and reinsertion at the tricuspid annulus are performed in the same way as in the Carpentier repair. ${ }^{31-33}$ However, instead of a plication, Wu advocates a resection of a triangular piece of the posterior part of the atrialized ventricle. Wu further describes the use of autologous pericardium if sufficient septal tissue is missing. ${ }^{32}$

\section{Hetzer Technique}

Hetzer describes various techniques for Ebstein's repair. ${ }^{25,34}$ Their key feature is annular plication. The posterior part of the tricuspid annulus is connected to the septal part of the tricuspid annulus. In some cases, Hetzer suggested the creation of a double orifice annulus. By approaching two points at the opposite side of the true annulus (septal and anteposterior), two orifices are created. The RV is not plicated and the thin myocardium of the atrialized ventricle remains in the RV. The leaflets are not mobilized.

\section{Sebening Stitch}

The Sebening stitch transfers the chordal attachment of the papillary muscle of the anterior leaflet to the septum close to 


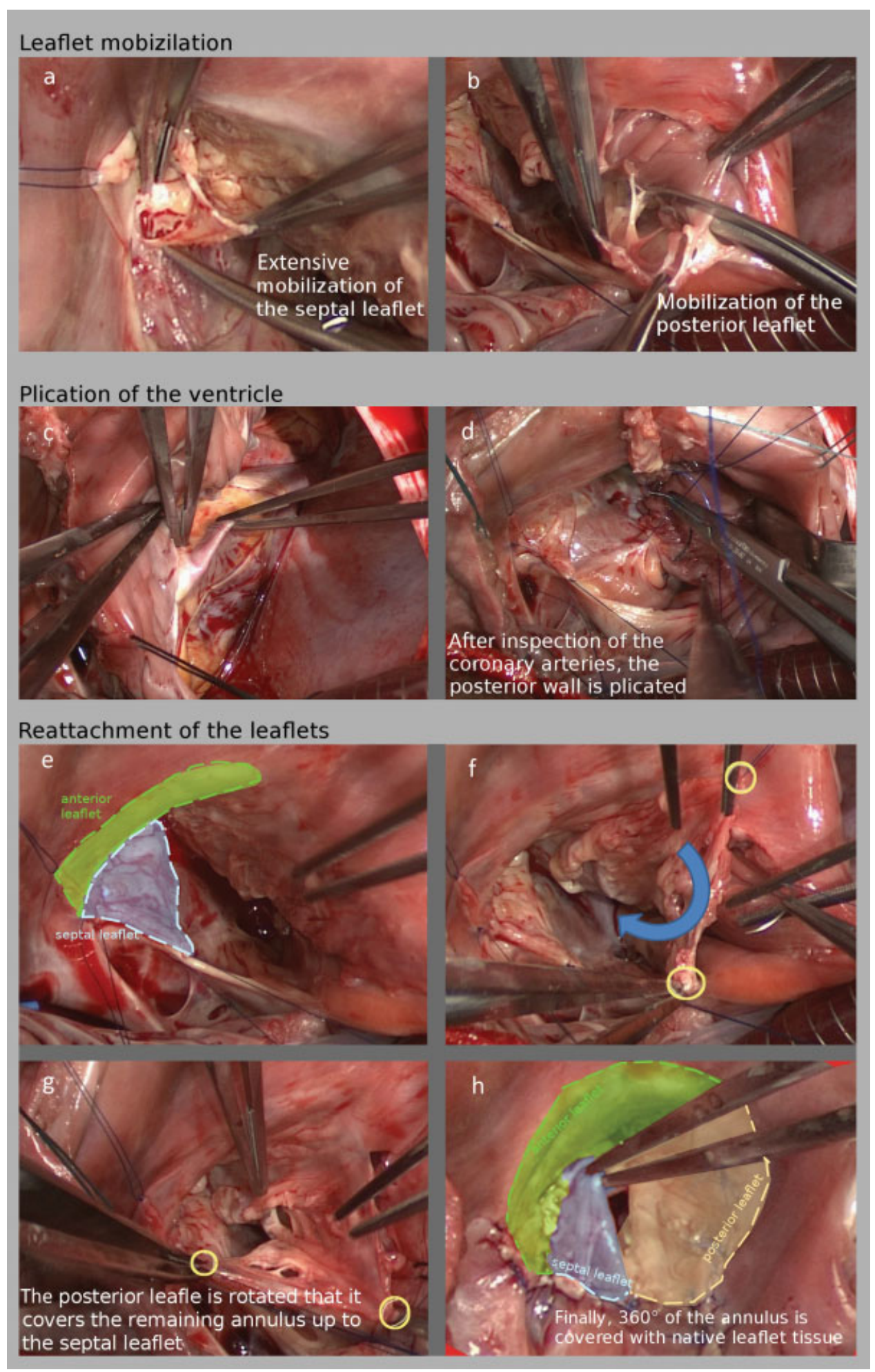

Fig. $4(\mathrm{a}-\mathrm{h})$ The cone procedure, step by step.

the "true" annulus. This procedure creates a monocusp valve because the posterior and the septal leaflet are both excluded. The anterior leaflet, which is usually fairly mobile, coapts with the septal rim of the "true" annulus. Although the Sebening stitch alone may result in a sufficient tricuspid valve, ${ }^{35,36}$ nowadays, it is mostly performed as an additional measure in combination with other repair techniques. ${ }^{30,37,38}$

\section{Surgical Technique: Replacement}

The prosthesis is placed at the height of the true tricuspid annulus. A horizontal plication of the annulus is usually required. To avoid damage to the atrioventricular (AV) node, some surgeons suggest to place the septal suture line in front of the coronary sinus, thus draining the coronary 
sinus into the right ventricle. ${ }^{23,39}$ The valve tissue may be removed or left in place. ${ }^{39}$ Tissue near the outflow tract can cause obstruction and should be removed. ${ }^{23}$ On the posterolateral aspect, the tissue is very thin and the suture line should therefore be deviated toward the atrium to avoid coronary artery injury. ${ }^{23}$ In addition to the valve replacement, the atrialized ventricular myocardium should be reduced by plication. ${ }^{40}$

\section{Surgical Technique: Further Considerations}

\section{ASD Closure}

ASD closure is recommended by the current guidelines of the European and American Society of Cardiology. ${ }^{41,42}$ Usually, a direct suture is sufficient for the ASD closure. To prevent RV failure, a residual interatrial shunt may be left. In case of RV failure, right atrial pressure increases and a right to left atrial shunt unloads the RV. ${ }^{13,29,43}$ We recommend to leave a $5 \mathrm{~mm}$ ASD in all patients treated with the cone procedure. If the residual shunt later leads to exercise intolerance and cyanosis, the ASD may be closed interventionally, but most patients remain free of any symptoms. ${ }^{13,29}$ A potential drawback of the residual interatrial shunt is the remaining risk of paradoxical embolism.

\section{Antiarrhythmic Strategy}

Some studies suggest that after tricuspid valve repair without concomitant antiarrhythmic surgery, two-thirds of patients who initially present with arrhythmias remain free of symptoms in the follow-up. ${ }^{44,45}$ Nevertheless, concomitant antiarrhythmic surgery should be considered. ${ }^{46}$ Antiarrhythmic surgical procedures may be divided into (1) procedures for accessory pathways or AV-nodal reentry tachycardia and (2) procedures for atrial fibrillation or flutter.

Procedures for accessory pathways or AV-nodal reentry tachycardia have lost their significance due to catheter ablation techniques. The intraoperative mapping and dissection of those pathways was initially introduced by Sealy and coworkers in $1963 .{ }^{47}$ This procedure has nowadays become a rarity, because patients usually undergo catheter ablation prior to cardiac surgery. Similarly, slow-pathway ablation for AV-nodal reentry tachycardia is usually performed by catheter. Nevertheless, Bockeria and coworkers reported in 2005 that intracardial mapping and ablation accessory pathways had a higher success rate than the transcatheter ablation in patients with Ebstein's anomaly. ${ }^{48}$

In contrast to the abandoned surgical procedures for accessory pathways, the maze procedure for atrial flutter is a current and successful antiarrhythmic surgical procedure. The placement of a set of ablation lines creates a maze for the electrical activation on the atrial wall. Instead of a planar propagation, the electrical activity propagates inside numerous blind-ending paths. Thus a (macro-) electrical circuit resulting in atrial fibrillation of flutter is prevented. ${ }^{49}$ Both a maze limited to the right side and biatrial maze are applied successfully in patients with Ebstein's anomaly, with a success rate of $93 \% .{ }^{50}$ Some surgeons recommend the addition of a cavotricuspid ablation line even in patients without previous arrhythmia to prevent isthmus-dependent flutter. $^{50}$

\section{Bailout in Case of Right Heart Failure}

Cardiac decompensation due to impaired RV function is a major concern after tricuspid valve surgery for Ebstein's disease, since afterload may be increased by the competency of the tricuspid valve when the blood is ejected only into the pulmonary artery. Consequently, RV stroke volume and ejection fraction decrease. On the other hand, volume load, i.e., preload of the right ventricle is also reduced and in most cases, may compensate for the increase in the afterload. In the early postoperative phase, beginning with weaning from the heart lung machine, the risk for RV failure is high. ${ }^{13}$ A temporary solution is to unload the $\mathrm{RV}$ by extracorporal membrane oxygenation (ECMO) in the postoperative phase. ${ }^{13}$ A permanent solution is the creation of a bidirectional cavopulmonary anastomosis (Glenn anastomosis). This "one and a half ventricle repair" can only be performed if pulmonary artery pressure is not elevated. ${ }^{51,52}$ In patients with a 1.5 ventricle repair, the flow over the tricuspid valve is diminished, and a mechanical prosthesis should be avoided due to increased risk of thrombosis. $^{53}$

\section{Results after Surgery}

- Table 2 shows the outcomes after different types of surgery in large patient collectives.

Table 2 Long-term outcome after Ebstein's repair or replacement

\begin{tabular}{|l|l|l|l|l|}
\hline Publication & Technique & Patients & Mortality & Reoperations \\
\hline Brown et $\mathrm{al}^{23}$ & Replacement & 378 & $6 \%$ early, $17 \%$ after 10 years & $41 \%$ after 20 years \\
\hline Brown et $\mathrm{al}^{23}$ & Danielson & 182 & $5 \%$ early, $12 \%$ after 10 years & $36 \%$ after 20 years \\
\hline Badiu et $\mathrm{al}^{24}$ & Sebening & 130 & $2.6 \%$ early, $13 \%$ after 10 years & $38 \%$ after 20 years \\
\hline Hetzer et $\mathrm{al}^{25}$ & Hetzer & 68 & $2.4 \%$ early, $8.7 \%$ after 10 years & $7.1 \%$ after 20 years \\
\hline${\text { Chavaud et } \text { al }^{57}}_{\text {da-Silva et } \mathrm{al}^{29}}^{\text {Carpentier }}$ & Cone & 91 & $9 \%$ early, $13 \%$ after 10 years & $11 \%$ after 20 years \\
\hline
\end{tabular}




\section{Repair versus Replacement}

In a single-center study from the Mayo Clinic, Brown and coworkers found no difference in survival following replacement and repair (Danielson technique). ${ }^{23}$ In patients below 12 years of age, freedom from reoperation was lower after repair than after replacement. There was no difference in freedom from reoperation in patients over 12 year of age ( $80 \%$ after 10 years). Today, repair is generally considered as the first-line treatment.

\section{Replacement: Biological versus Mechanical}

In a recent retrospective study, Brown and coworkers reported similar rates of reoperation after implantation of a mechanical or biological prosthesis in patients with Ebstein's disease. However, survival was longer after the implantation of a biological prosthesis. ${ }^{54}$ An important limitation of this study is that age was significantly higher in patients undergoing replacement with a mechanical device. Furthermore, $69 \%$ of the mechanical valves were ball and cage prostheses, which meanwhile have been replaced by bileaflet valves. Barlett and coworkers performed a retrospective multicenter study including children below 6 years of age undergoing tricuspid valve repair. While there was no significant difference in survival after replacement using a mechanical or biological prosthesis, the use of a mechanical prosthesis was associated with a higher rate of failure (twofold) and a higher risk for pacemaker implantation (13-fold). ${ }^{55}$ Generally, a biological prosthesis should be recommended independent of the age of the patient. These prostheses may become dysfunctional early, especially in patients younger than 16 years of age, but a redooperation can be performed with a low mortality. ${ }^{56}$

Some authors suggest that due to the low opening and low closing pressure at the tricuspid position, porcine bioprostheses are more suitable compared with pericardial bioprostheses because of their thinner leaflet tissue. ${ }^{53}$

\section{Types of Repair}

Till date, no comparative study among different types of repair has been performed. Both the Mayo Clinic (2008, Danielson technique) $)^{23}$ and the German Heart Centre Munich (2010, predominantly Sebening stitch) ${ }^{24}$ reported an excellent early and long-term survival after repair but considerable rate of reoperation in the long-term follow-up (36 and 38\% reoperation after 20 years). In contrast, the group of the Hospital George Pompidou, Paris (2003, Carpentier technique $)^{57}$ reported considerably less reoperations in the long-term follow-up than the other two groups. Likewise, the percentage of repair procedures (98\%) was higher compared with the German Heart Centre (90\%) or the Mayo Clinic (34\%). In 2007, the group of the Hospital Beneficencia Portuguesa, Sao Paolo (cone technique) reported an excellent survival and few need for reoperation ${ }^{29}$ in 40 consecutive patients with Ebstein's anomaly.

In consequence of the excellent results from the group in Sao Paolo with the cone repair, many groups with an extensive experience in the repair of Ebstein's anomaly such as the Mayo Clinic in Rochester, ${ }^{30}$ the German Heart
Centre in Munich, ${ }^{13}$ the great Ormond Street Hospital for Sick Children in London, ${ }^{58}$ and the Children's Hospital in Boston ${ }^{59}$ switched to this technique. Furthermore, the cone technique was adopted by the two highly frequented hospitals-West China Hospital, Chengdu ${ }^{60}$ and the Shanghai Children's Medical Center. ${ }^{61}$ It is noteworthy that the favorable results with regard to mortality, valve competency, and the high percentage of achieved repair could be reproduced by all of these groups. Furthermore, MRI measurements show a major change in RV size and shape after the cone repair. At the German Heart Centre, the preoperatively indexed enddiastolic volume of the functional RV was $191 \mathrm{~mL}^{2}$ (normal value: $75 \mathrm{~mL} / \mathrm{m}^{2}$ ) and was reduced to $123 \mathrm{~mL} / \mathrm{m}^{2} 6$ months after the repair. The group of Chengdu reported similar results (index preoperative RV end-diastolic volume: $134 \mathrm{~mL} / \mathrm{m}^{2}$ reduced to $97 \mathrm{~mL} / \mathrm{m}^{2}$ postoperatively). According to the law of Laplace, a reduction of RV diameter results in a reduction in wall stress. Thus, there is a good reason to assume that the cone repair may prevent a later heart failure. The RV ejection fraction remains impaired in the midterm follow-up, but the regurgitation volume decreases. The net result is an increased flow over the pulmonary artery ${ }^{13}$ and an improved left ventricular filling. ${ }^{58}$ Cardiopulmonary exercise testing displays an improved functional status in the midterm follow-up after the cone repair.

\section{Special Case: Newborn}

\section{Pathology}

During the first weeks of life, a newborn with Ebstein's disease may present with an aggravated physiologic condition. Right ventricular function is impaired by the presence of severe tricuspid valve insufficiency. At the same time, the pulmonary pressure is physiologically elevated, putting additional stress on the RV. In this situation, severe congestive failure may evolve rapidly and the patients may have to be assigned to surgery in the neonatal period. However, in some cases, symptoms may diminish with the physiologic decline in pulmonary artery pressure. The therapeutic goal in severe neonatal Ebstein anomaly is not "earliest surgery," but medical management including measures to reduce the pulmonary vascular resistance (even with prostaglandin infusion in the beginning). When weaning from prostaglandin E fails, it serves as an indication for an early surgery. Celermajer and coworkers developed an echocardiographic score (Great Ormond Street Echo score, GOSE score) to help the physicians in this situation to decide between an early surgery or medical treatment until later repair ${ }^{61}$ (-Fig. 5).

Accordingly, the disease can be graduated, and a mortality risk can be determined ( - Table 3 ).

\section{Palliation: Starnes Procedure}

The first series on successful palliative surgery in neonatal patients with Ebstein's disease was published in 1991 by Starnes. ${ }^{62}$ In this procedure, the tricuspid valve orifice is closed with a membrane at the true tricuspid annulus and the pulmonary artery is ligated. An atrioseptectomy and a modified Blalock-Taussig shunt are added. 


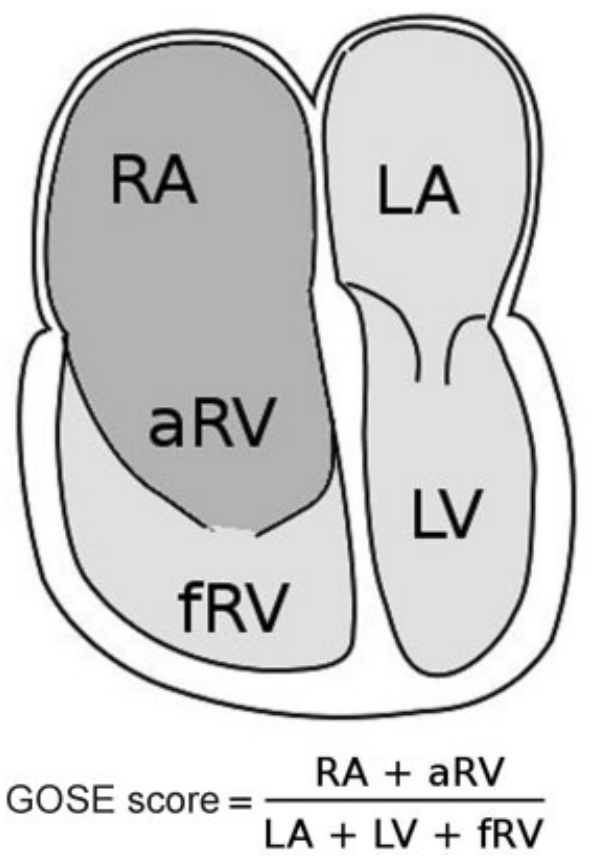

Fig. 5 Calculation of the Great Ormond Street Echo Score according to Celermejer et al, 1992. aRV, atrialized right ventricle; fRV, functional right ventricle; LA, left atrium; LV, left ventricle; RA, right atrium.

A certain amount of blood still drains into the $\mathrm{RV}$ via the perforant veins. In a later experience of the Starnes group (16 patients), the importance of leaving a small hole in the membrane was emphasized to decompress the $\mathrm{RV}^{63,64}$ This improved survival after a mean follow-up of 27 months from 66 to $80 \%$.

\section{Correction: Knott-Craig}

In 2000, Knott Craig and coworkers published three cases of neonates with Ebstein's anomaly undergoing repair of the tricuspid valve. ${ }^{65}$ GOSE-scores were $1.3,1.8$, and 2.4 with a high probability of death without surgery. ${ }^{61}$ The authors created a monocuspid valve consisting of the anterior leaflet only and added a bidirectional cavopulmonary anastomosis. An annular plication was performed by placing a suture with one pledgeted end at the anterior-posterior commissure and the other pledgeted end at the coronary sinus. By connecting these two points, the annulus is divided into a bigger orifice (containing the anterior valve and part of the remnants of the septal valve) and a smaller orifice at the posterior wall

Table 3 Survival rates of neonates with Ebstein's anomaly

\begin{tabular}{|l|l|l|}
\hline Score & & Natural course \\
\hline$<0.5$ & GOSE I & $0 \%$ Mortality \\
\hline $0.5-0.99$ & GOSE II & $10 \%$ Mortality \\
\hline $1-1.49$ & GOSE III & $44 \%$ Mortality \\
\hline$\geq 1.5$ & GOSE IV & $100 \%$ Mortality \\
\hline
\end{tabular}

Abbreviation: GOSE, Great Ormond Street Echo. (containing the posterior valve). The smaller orifice is closed by a running suture. At the bigger orifice, the anterior leaflet can coapt with the septum and act as a monocuspid valve. As a further modification, the septal leaflet may be detached at the annulus if the anterior leaflet is adherent and therefore not able to coapt with the septal wall. ${ }^{66}$ At the place of the detachment, a patch is inserted to enlarge the anterior leaflet.

In 2011, the group of Knott-Craig reported 32 neonates and young children, of which $90 \%$ underwent biventricular repair. GOSE score was $\geq 1$ in all patients and $\geq 1.5$ in 22 patients. Early mortality was $22 \%$ and there was one late death. ${ }^{67}$ Freedom from reoperation after 15 years was $75 \%$ in patients undergoing biventricular repair.

Recently, most centers with extensive experience with the cone procedure have also started to apply this technique in newborn children if there is enough valve tissue for the reconstruction. Since it is still a preliminary experience, this information is based on personal communication only.

\section{Conclusion}

Surgical repair of Ebstein's anomaly has been a challenge for decades. Since the first description by Hunter and Lillehei in 1957, many different repair techniques have evolved. Plication procedures alone yielded acceptable results but were characterized by a considerable reoperation rate. With the advent of complex leaflet reconstruction techniques, such as the Carpentier and the cone reconstruction, a more physiologic repair became available. In particular, the cone reconstruction shows very promising results and may become the technique of choice for patients with Ebstein's anomaly.

\section{References}

1 Correa-Villaseñor A, Ferencz C, Neill CA, Wilson PD, Boughman JA; The Baltimore-Washington Infant Study Group. Ebstein's malformation of the tricuspid valve: genetic and environmental factors. Teratology 1994;50(02):137-147

2 Anderson KR, Lie JT. The right ventricular myocardium in Ebstein's anomaly: a morphometric histopathologic study. Mayo Clin Proc 1979;54(03):181-184

3 Edmar A. Case 1/2015 A 76-year-old male patient with ebstein anomaly in natural course. Arquivos brasileiros de cardiologia 2015;104 (01):e1-e3

4 Ebstein W. Über einen sehr seltenen Fall von Insufficienz der Valvula tricuspidalis, bedingt durch eine angeborene hochgradige Missbildung derselben. Archiv Für Anatomie, Physiologie Und Wissenschaftliche Medicin 1866:238-254

5 Soloff LA, Stauffer HM, Zatuchni J. Ebstein's disease: report of the first case diagnosed during life. Am J Med Sci 1951;222(05): 554-561

6 Burchell HB, Dushane JW, Kilby RA, Wood EH. Ebstein's malformation: a clinical and laboratory study. Medicine (Baltimore) 1956;35(03):161-185

7 Hunter SW, Lillehei CW. Ebstein's malformation of the tricuspid valve; study of a case together with suggestion of a new form of surgical therapy. Dis Chest 1958;33(03):297-304

8 Hardy KL, May IA, Webster CA, Kimball KG. Ebstein's anomaly: a functional concept and successful definitive repair. J Thorac Cardiovasc Surg 1964;48:927-940 
9 Barnard CN, Schrire V. Surgical correction of ebstein's malformation withprosthetic tricuspid valve. Surgery 1963;54:302-308

10 Van Mierop LH, Gessner IH. Pathogenetic mechanisms in congenital cardiovascular malformations. Prog Cardiovasc Dis 1972; 15(01):67-85

11 Schreiber C, Cook A, Ho SY, Augustin N, Anderson RH. Morphologic spectrum of Ebstein's malformation: revisitation relative to surgical repair. J Thorac Cardiovasc Surg 1999;117(01):148-155

12 Fratz S, Janello C, Müller D, et al. The functional right ventricle and tricuspid regurgitation in Ebstein's anomaly. Int J Cardiol 2013; 167(01):258-261

13 Lange R, Burri M, Eschenbach LK, et al. Da Silva's cone repair for Ebstein's anomaly: effect on right ventricular size and function. Eur J Cardiothorac Surg 2015;48(02):316-320; discussion 320321

14 Anderson KR, Zuberbuhler JR, Anderson RH, Becker AE, Lie JT. Morphologic spectrum of Ebstein's anomaly of the heart: a review. Mayo Clin Proc 1979;54(03):174-180

15 Daliento L, Angelini A, Ho SY, et al. Angiographic and morphologic features of the left ventricle in Ebstein's malformation. Am J Cardiol 1997;80(08):1051-1059

16 Celermajer DS, Dodd SM, Greenwald SE, Wyse RK, Deanfield JE. Morbid anatomy in neonates with Ebstein's anomaly of the tricuspid valve: pathophysiologic and clinical implications. J Am Coll Cardiol 1992;19(05):1049-1053

17 Driscoll DJ, Mottram CD, Danielson GK. Spectrum of exercise intolerance in 45 patients with Ebstein's anomaly and observations on exercise tolerance in 11 patients after surgical repair. J Am Coll Cardiol 1988;11(04):831-836

18 Attenhofer Jost CH, Connolly HM, Scott CG, Burkhart HM, Ammash NM, Dearani JA. Increased risk of possible paradoxical embolic events in adults with ebstein anomaly and severe tricuspid regurgitation. Congenit Heart Dis 2014;9(01):30-37

19 Roten L, Lukac P, DE Groot N, et al. Catheter ablation of arrhythmias in ebstein's anomaly: a multicenter study. J Cardiovasc Electrophysiol 2011;22(12):1391-1396

20 Hebe J. Ebstein's anomaly in adults. Arrhythmias: diagnosis and therapeutic approach. Thorac Cardiovasc Surg 2000;48(04): 214-219

21 Rossi L, Thiene G. Mild Ebstein's anomaly associated with supraventricular tachycardia and sudden death: clinicomorphologic features in 3 patients. Am J Cardiol 1984;53(02):332-334

22 Attie F, Rosas M, Rijlaarsdam M, et al. The adult patient with Ebstein anomaly. Outcome in 72 unoperated patients. Medicine (Baltimore) 2000;79(01):27-36

23 Brown ML, Dearani JA, Danielson GK, et al; Mayo Clinic Congenital Heart Center. The outcomes of operations for 539 patients with Ebstein anomaly. J Thorac Cardiovasc Surg 2008;135(05):1120-1136; 1136.e1-1136.e7

24 Badiu CC, Schreiber C, Hörer J, et al. Early timing of surgical intervention in patients with Ebstein's anomaly predicts superior long-term outcome. Eur J Cardiothorac Surg 2010;37(01):186-192

25 Hetzer R, Hacke P, Javier M, et al. The long-term impact of various techniques for tricuspid repair in Ebstein's anomaly. J Thorac Cardiovasc Surg 2015;150(05):1212-1219

26 Brown ML, Dearani JA, Danielson GK, et al. Effect of operation for Ebstein anomaly on left ventricular function. Am J Cardiol 2008; 102(12):1724-1727

27 Danielson GK, Maloney JD, Devloo RA. Surgical repair of Ebstein's anomaly. Mayo Clin Proc 1979;54(03):185-192

28 Carpentier A, Chauvaud S, Macé L, et al. A new reconstructive operation for Ebstein's anomaly of the tricuspid valve. J Thorac Cardiovasc Surg 1988;96(01):92-101

29 da Silva JP, Baumgratz JF, da Fonseca L, et al. The cone reconstruction of the tricuspid valve in Ebstein's anomaly. The operation: early and midterm results. J Thorac Cardiovasc Surg 2007;133 (01):215-223
30 Dearani JA, Said SM, O'Leary PW, Burkhart HM, Barnes RD, Cetta F. Anatomic repair of Ebstein's malformation: lessons learned with cone reconstruction. Ann Thorac Surg 2013;95(01):220-226; discussion 226-228

$31 \mathrm{Wu}$ Q Huang Z. Anatomic correction of Ebstein anomaly. J Thorac Cardiovasc Surg 2001;122(06):1237-1238

$32 \mathrm{Wu} \mathrm{Q}$ Huang Z. A new procedure for Ebstein's anomaly. Ann Thorac Surg 2004;77(02):470-476; discussion 476

33 Wu Q, Huang Z, Pan G, Wang L, Li L, Xue H. Early and midterm results in anatomic repair of Ebstein anomaly. J Thorac Cardiovasc Surg 2007;134(06):1438-1440; discussion 1440-1442

34 Hetzer R, Nagdyman N, Ewert P, et al. A modified repair technique for tricuspid incompetence in Ebstein's anomaly. J Thorac Cardiovasc Surg 1998;115(04):857-868

35 Schmidt-Habelmann P, Meisner H, Struck E, Sebening F. Results of valvuloplasty for Ebstein's anomaly. Thorac Cardiovasc Surg 1981;29(03):155-157

36 Augustin N, Schmidt-Habelmann P, Wottke M, Meisner H, Sebening F. Results after surgical repair of Ebstein's anomaly. Ann Thorac Surg 1997;63(06):1650-1656

37 Komoda T, Komoda S, Nagdyman N, Berger F, Hetzer R. Combination of a Hetzer operation and a Sebening stitch for Ebstein's anomaly. Gen Thorac Cardiovasc Surg 2007;55(09):355-359

38 Ullmann MV, Born S, Sebening C, Gorenflo M, Ulmer HE, Hagl S. Ventricularization of the atrialized chamber: a concept of Ebstein's anomaly repair. Ann Thorac Surg 2004;78(03): 918-924; discussion 924-925

39 Raj Behl P, Blesovsky A. Ebstein's anomaly: sixteen years' experience with valve replacement without plication of the right ventricle. Thorax 1984;39(01):8-13

40 Timmis HH, Hardy JD, Watson DG. The surgical management of Ebstein's anomaly. The combined use of tricuspid valve replacement, atrioventricular plication, and atrioplasty. J Thorac Cardiovasc Surg 1967;53(03):385-391

41 Warnes CA, Williams RG, Bashore TM, et al; ACC/AHA 2008 guidelines for the management of adults with congenital heart disease. J Am Coll Cardiol 2008;52(23):e143-e263

42 Baumgartner H, Bonhoeffer P, De Groot NMS, et al; Task Force on the Management of Grown-up Congenital Heart Disease of the European Society of Cardiology (ESC); Association for European Paediatric Cardiology (AEPC); ESC Committee for Practice Guidelines (CPG). ESC Guidelines for the management of grown-up congenital heart disease (new version 2010). Eur Heart J 2010;31(23):2915-2957

43 Lillehei CW, Kalke BR, Carlson RG. Evolution of corrective surgery for Ebstein's anomaly. Circulation 1967;35(4, Suppl)I111-I118

44 Chauvaud SM, Brancaccio G, Carpentier AF. Cardiac arrhythmia in patients undergoing surgical repair of Ebstein's anomaly. Ann Thorac Surg 2001;71(05):1547-1552

45 Oh JK, Holmes DR Jr, Hayes DL, Porter CBJ, Danielson GK. Cardiac arrhythmias in patients with surgical repair of Ebstein's anomaly. J Am Coll Cardiol 1985;6(06):1351-1357

46 Huang CJ, Chiu IS, Lin FY, et al. Role of electrophysiological studies and arrhythmia intervention in repairing Ebstein's anomaly. Thorac Cardiovasc Surg 2000;48(06):347-350

47 Cobb FR, Blumenschein SD, Sealy WC, Boineau JP, Wagner GS, Wallace AG. Successful surgical interruption of the bundle of Kent in a patient with Wolff-Parkinson-White syndrome. Circulation 1968;38(06):1018-1029

48 Bockeria L, Golukhova E, Dadasheva M, et al. Advantages and disadvantages of one-stage and two-stage surgery for arrhythmias and Ebstein's anomaly. Eur J Cardiothorac Surg 2005;28(04):536-540

49 Cox JL. Cardiac surgery for arrhythmias. Pacing Clin Electrophysiol 2004;27(02):266-282

50 Stulak JM, Dearani JA, Puga FJ, Zehr KJ, Schaff HV, Danielson GK. Right-sided maze procedure for atrial tachyarrhythmias in congenital heart disease. Ann Thorac Surg 2006;81(05):1780-1784; discussion 1784-1785 
51 Liu J, Qiu L, Zhu Z, Chen H, Hong H. Cone reconstruction of the tricuspid valve in Ebstein anomaly with or without one and a half ventricle repair.J Thorac Cardiovasc Surg 2011;141(05):1178-1183

52 Chauvaud S, Fuzellier JF, Berrebi A, et al. Bi-directional cavopulmonary shunt associated with ventriculo and valvuloplasty in Ebstein's anomaly: benefits in high risk patients. Eur J Cardiothorac Surg 1998;13(05):514-519

53 Dearani JA. Editorial comment: lessons learned with tricuspid valve replacement. Eur J Cardiothorac Surg 2014;45(01):90-91

54 Brown ML, Dearani JA, Danielson GK, et al. Comparison of the outcome of porcine bioprosthetic versus mechanical prosthetic replacement of the tricuspid valve in the Ebstein anomaly. Am J Cardiol 2009;103(04):555-561

55 Bartlett HL, Atkins DL, Burns TL, et al. Early outcomes of tricuspid valve replacement in young children. Circulation 2007;115(03):319-325

56 Burri M, Vogt MO, Hörer J, et al. Durability of bioprostheses for the tricuspid valve in patients with congenital heart disease. Eur J Cardiothorac Surg 2016;50(05):988-993

57 Chauvaud S, Berrebi A, d'Attellis N, Mousseaux E, Hernigou A, Carpentier A. Ebstein's anomaly: repair based on functional analysis. Eur J Cardiothorac Surg 2003;23(04):525-531

58 Ibrahim M, Tsang VT, Caruana M, et al. Cone reconstruction for Ebstein's anomaly: Patient outcomes, biventricular function, and cardiopulmonary exercise capacity. J Thorac Cardiovasc Surg 2015;149(04):1144-1150

59 Vogel M, Marx GR, Tworetzky W, et al. Ebstein's malformation of the tricuspid valve: short-term outcomes of the "cone procedure" versus conventional surgery. Congenit Heart Dis 2012;7(01):50-58
60 Liu X, Zhang Q Yang ZG, et al. Morphologic and functional abnormalities in patients with Ebstein's anomaly with cardiac magnetic resonance imaging: correlation with tricuspid regurgitation. Eur J Radiol 2016;85(09):1601-1606

61 Celermajer DS, Cullen S, Sullivan ID, Spiegelhalter DJ, Wyse RK, Deanfield JE. Outcome in neonates with Ebstein's anomaly. J Am Coll Cardiol 1992;19(05):1041-1046

62 Starnes VA, Pitlick PT, Bernstein D, Griffin ML, Choy M, Shumway NE. Ebstein's anomaly appearing in the neonate. A new surgical approach. J Thorac Cardiovasc Surg 1991;101(06):1082-1087

63 Reemtsen BL, Fagan BT, Wells WJ, Starnes VA. Current surgical therapy for Ebstein anomaly in neonates. J Thorac Cardiovasc Surg 2006;132(06):1285-1290

64 Reemtsen BL, Polimenakos AC, Fagan BT, Wells WJ, Starnes VA. Fate of the right ventricle after fenestrated right ventricular exclusion for severe neonatal Ebstein anomaly. J Thorac Cardiovasc Surg 2007;134(06):1406-1410; discussion 1410-1412

65 Knott-Craig CJ, Overholt ED, Ward KE, Razook JD. Neonatal repair of Ebstein's anomaly: indications, surgical technique, and medium-term follow-up. Ann Thorac Surg 2000;69(05): $1505-1510$

66 Knott-Craig CJ, Goldberg SP, Overholt ED, Colvin EV, Kirklin JK. Repair of neonates and young infants with Ebstein's anomaly and related disorders. Ann Thorac Surg 2007;84(02):587-592; discussion 592-593

67 Boston US, Goldberg SP, Ward KE, et al. Complete repair of Ebstein anomaly in neonates and young infants: a 16-year follow-up. J Thorac Cardiovasc Surg 2011;141(05):1163-1169 